\title{
Geochemistry of Birimian phyllites from the Obuasi and Prestea Mines, Southwestern Ghana: Implications for provenance and source- area weathering
}

\author{
Manu, Johnson, Asiedu, Daniel K* And Anani, Chris Y \\ Department of Geology, University of Ghana, P. O. Box LG 58, Legon, Ghan \\ *Corresponding author E-mail: dasiedu@ug.edu.gh
}

\begin{abstract}
Phyllites from the Ashanti Belt of the Paleoproterozoic Birimian rocks of Ghana were analyzed for their major and trace element geochemistry in order to constrain their provenance and source area weathering. The analyses of the phyllites generally define a single geochemical group by their major- and trace-element abundances. The metamorphosed sediments may be classified as immature by their high index of compositional variability values of mostly $>1$. High field strength elements are generally depleted whereas transition metals are typically enriched relative to average Proterozoic upper crust. Such geochemical characteristics suggest that the source of the phyllites dominantly consisted of mafic rocks. Average $\mathrm{Cr}$ and $\mathrm{Ni}$ abundances and $\mathrm{Cr} / \mathrm{Ni}$ ratios of average phyllites of the Birimian metasediments indicate that the source consisted of basaltic material. Major element data, plotted in $\mathrm{Al}_{2} \mathrm{O}_{3}-\left(\mathrm{CaO}+\mathrm{Na}_{2} \mathrm{O}\right)-\mathrm{K}_{2} \mathrm{O}$ ternary diagram indicate that the phyllites have undergone significant post-depositional $\mathrm{K}$ metasomatism. Low to moderately high chemical weathering of the source terrane is indicated by premetasomatized chemical index of alteration values of $55-85$. The geochemical data further suggest that the sediments were deposited within an active continental margin setting and mostly supplied by the adjacent volcanic belts.
\end{abstract}

Keywords: Birimian, Geochemistry, Ghana, Phyllites, Provenance

\section{Introduction}

The notion that there is a record of geologic history within the chemical composition of sedimentary rocks is well established. Geochemical studies of terrigenous sedimentary rocks have provided critical information regarding provenance, source-area weathering conditions, and estimates of average upper crustal composition through time [1, 2, 3]. This observation has been especially true for Precambrian terranes for which, in many cases, source areas have been eroded away or remain conjectural. In addition, geochemical studies have added much to the understanding of the growth of the continental crusts through time $[4,5]$.

Owing to their grain size homogeneity and post-depositional impermeability, the chemical composition of fine-grained siliciclastic sedimentary rocks have proved very useful in evaluating the nature of their source lithology and paleoclimate conditions, in the identification of tectonic and crustal extraction events, and in the understanding of crustal and mantle evolution. Indeed, the present level of understanding of crustal evolution comes mainly from geochemical and isotopic data gathered on fine-grained sedimentary rocks $[4,6]$.

Of the major Precambrian cratons exposed on Earth, only the sedimentary rocks of the West African Craton (Fig. 1) remain to be subjected to detailed geochemical and isotopic studies despite earlier attempts by Boher et al. [7], Taylor et al. [8], Asiedu et al. [9, 10], Karikari et al. [11] and Roddaz et al. [12]. It is therefore not surprising that sedimentary rocks from the West African Craton, one of the most extensive outcrops of Paleoproterozoic rocks on earth [13], by and large remain unrepresented in any computed model for crustal composition.

In order to contribute to the study of Precambrian sedimentary rocks of the West African craton that can be used for the computation of crustal composition we present a paper on Birimian phyllites from the Obuasi and Prestea mines (Fig. 2). This paper discusses the nature of source rocks and the paleoclimatic conditions in the source area and at the time of deposition. In addition, the geochemical data generated can be useful for future computation of the crustal composition of the West African Craton at $~ 2.1 \mathrm{Ga}$. 


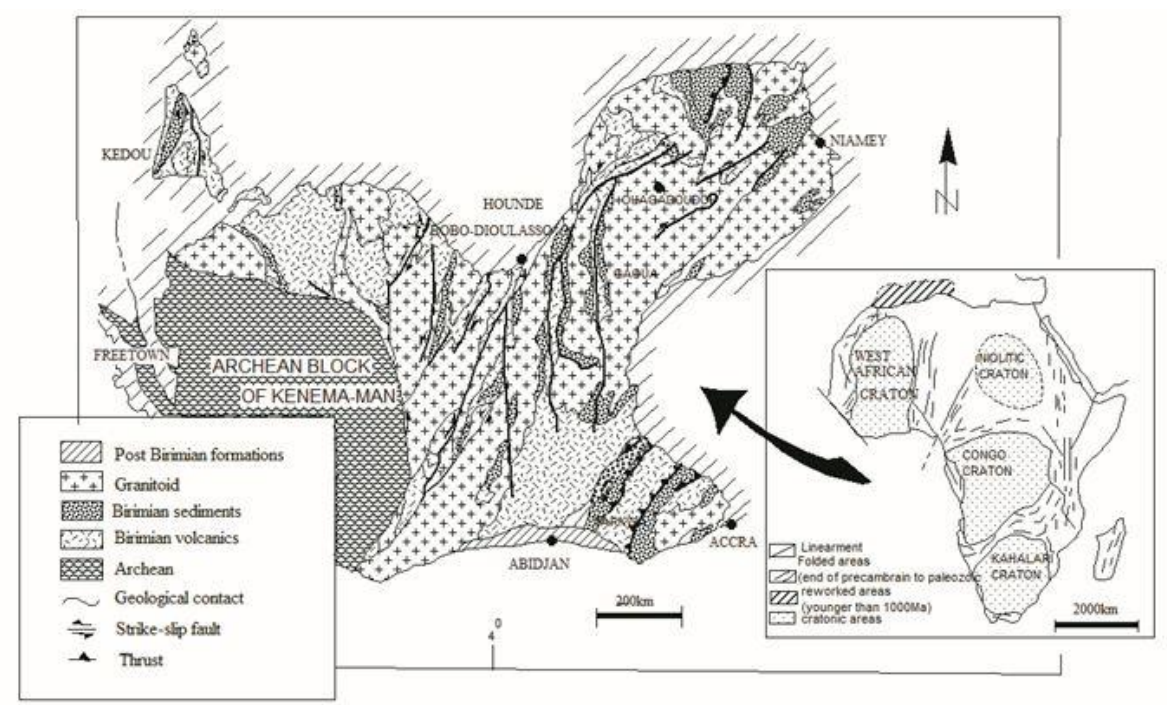

Fig. 1: Simplified map showing the West African craton modified after Milesi et al., [29]

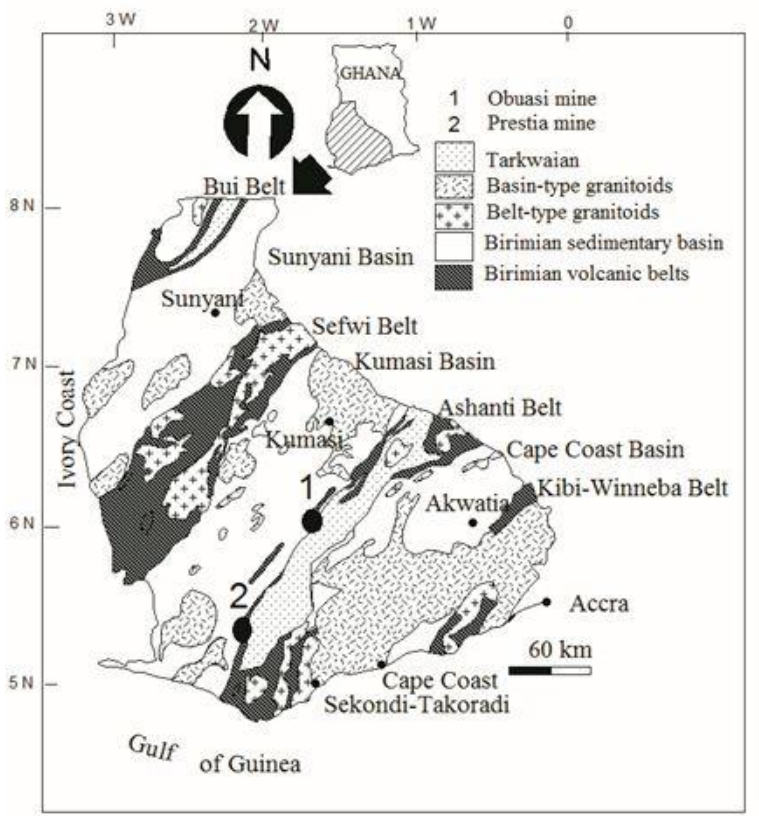

Fig. 2: Geological map of Ghana showing the study area

\section{Materials and methods}

The samples for this study were taken from the Obuasi and Prestea mines which fall within the Birimian terrane recognised in Ghana as northeasterly striking belts of metasedimentary-volcanic rocks, which are intruded by syntectonic and late-tectonic suites of granitoids. The Birimian assemblage formed around 2100 Ma during the early Proterozoic [14] and is $10-15 \mathrm{~km}$ thick [15]. The rocks dip steeply and are isoclinally folded. Subdivisions of the Birimian are the Lower Birimian and the Upper Birimian which represent mainly metasedimentary and metavolcanic sequences respectively. The rock units of the metasediments (i.e. Lower Birimian) are primarily phyllites and greywackes. There are also weakly metamorphosed tuffs, feldspathic sandstones and $\mathrm{Mn}$ - and Si-rich chemical sediments. Carbonaceous matter is present in most of the phyllites. The rock units of the metavolcanics (i.e. Upper Birimian) are predominantly tholeiitic basalt and pyroclastic rocks. There are also some mafic to ultramafic intrusions. 


\section{Petrography}

Megascopically, the phyllites have a planar to crumple foliation. The grey-green to light-green pure phyllites and ankerite phyllites are evenly foliated with "dull" pronounced lustre whereas the graphite phyllites are black and have silky lustre. The phyllitic rocks, particularly the graphite ankerite phyllites occasionally contain pyrites.

In thin section, fine sericite flakes form bundles and together with fine quartz grains define the foliation. Small tabular muscovite crystals $(40 \times 10 \mu \mathrm{m})$ are rare. Big quartz grains can occur sub-rounded $(400 \mu \mathrm{m})$, longitudinal $(1.4 \mathrm{~mm})$ or lens-shaped. Occasionally, there is recrystallisation and re-orientation of the quartz gains. Fine- to medium grained Carlsbad-twinned albite and polysynthetic oligoclase are also sub-rounded $(100 \mu \mathrm{m})$ and tend to be fresh. The mica bend round or are pushed aside slightly by the quartz and feldspar grains which indicate quartz and feldspar formation before or during the matrix development.

Ankerite $(100 \mu \mathrm{m})$ occurs as irregular aggregates which are intergrown with tiny quartz grains or as small occasionally being replaced by opaques (or leucoxene)? Accessories are epidote, tourmaline and deep-blue interference colour chlorite (Fe-rich chlorite) which occurs after the sericite. The modal estimate of the pure phyllite is mica (50\%), quartz $(45 \%)$, ankerite $(2 \%)$ and accessories $(3 \%)$.

In the chlorite phyllite, the chlorite, as single tabular forms $(150 \times 20 \mu \mathrm{m})$ or aggregated big flakes has a light greygreen interference colour. It occurs within or across the foliation. The chlorite phyllite can be enriched in opaques. Sometimes the accessory epidote shows zoning.

In the graphite phyllite (modal estimate: quartz, 45\%; mica, 30\%; graphite, 18\%; ankerite, 5\%; accessories, $2 \%$ ), the increased amount of graphite is finely distributed in the foliation plane. Often the graphitic material forms bands which intercalate with quartz \pm sericite \pm ankerite and occasionally light grey interference colour chlorite (Mg-rich chlorite) bands. There can be abundance of chlorite giving graphite-chlorite phyllite.

The foliation bands are often folded and such phyllites have previously been described as contorted (carbonaceous) phyllites. The graphite phyllite shows such strong deformation especially at the contact to the metavolcanics. Most often adjacent to the quartz reef is a very fragile graphite phyllite often referred to by the local geologists as "fissure zone". Here the quartz grains show extreme deformational effects as deformation lamellae or granulation.

The quartz \pm ankerite \pm sericite \pm opaques \pm apatite \pm apatite paragenesis form lensoid pockets or short layers. The foliation bands are distorted and mainly marked by graphite. Quartz \pm sericite \pm Fe-rich chlorite can also form bands in the foliation. The graphite phyllites intercalates with pure phyllites.

\section{Geochemical analysis}

Crushing and pulverization of samples was done using standard procedures in the preparation of samples for wholerock geochemical analysis. The samples were analysed for the elements presented (except for LOI, Au and $\mathrm{Si}$ ) using a BAUSCH \& LOMB induced couple plasma emissions spectrometer (Type 3520). LOI (Loss on ignition) was determined thermo- gravimetrically. The analyses were performed by D. Zachman at Geochemical Laboratory, Technical University, Braunschweig, Germany. Si was determined on a PHILIPS X-ray fluorescence spectrometer (Type PW 1410/10) using fused glass discs (2700mg lithium tetraborate (Li2B407), 300mg lanthan oxide (La203) and $300 \mathrm{mg}$ fused sample).

\section{$5 \quad$ Results and discussion}

\subsection{Results}

The bulk-rock chemical data is shown in Table 1. The samples of the Birimian phyllites are characterized by low to moderate $\mathrm{SiO}_{2}$ concentrations (range from 44 to 72 wt. \%) and moderate to high $\mathrm{Fe}_{2} \mathrm{O}_{3}$ (total $\mathrm{Fe}$ as $\mathrm{Fe}_{2} \mathrm{O}_{3}$ ) $+\mathrm{MgO}$ contents 6 to 15 wt. \%. $\mathrm{Al}_{2} \mathrm{O}_{3} / \mathrm{SiO}_{2}$ ratios are fairly constant (range from 0.13 to 0.34 ), but $\mathrm{K}_{2} \mathrm{O} / \mathrm{Na}_{2} \mathrm{O}$ ratios are variable, ranging from 0.3 to 8.7. Using the geochemical classification diagram of Herron [16], the Birimian phyllites are classified as shale or wacke; one sample, however, fall in Fe-sand field (Fig. 3). This differentiation is due to high $\mathrm{SiO}_{2} / \mathrm{Al}_{2} \mathrm{O}_{3}$ ratios on the average for some of the graphite phyllites.

The $\mathrm{K}_{2} \mathrm{O} / \mathrm{Al}_{2} \mathrm{O}_{3}$ ratio of sediments can be used as an indicator of the original composition of ancient sediments. The $\mathrm{K}_{2} \mathrm{O} / \mathrm{Al}_{2} \mathrm{O}_{3}$ ratios for clay minerals and feldspars are different ( 0.0 to $0.3,0.3$ to 0.9 , respectively; [17]. In most of the samples the $\mathrm{K}_{2} \mathrm{O} / \mathrm{Al}_{2} \mathrm{O}_{3}$ ratios are close to the upper limit of the clay mineral range, which suggest that the illite is the dominant clay mineral in these phyllites. Cox et al. [17] indicates that the compositional trends in muds derived by weathering of progressively more granitic source material are similar to those in recycled muds; both become richer in 
$\mathrm{Al}_{2} \mathrm{O}_{3}$ and $\mathrm{K}_{2} \mathrm{O}$. This assertion is not the case in the Birrimian phyllites as the averages of both $\mathrm{Al}_{2} \mathrm{O}_{3}$ and $\mathrm{K}_{2} \mathrm{O}$ are 13.7 and 2.2 respectively, as compared to EPUC being 14.9 and 3.2.

Compared to average estimates of early Proterozoic crust [6] the Birimian phyllites have lower abundances of both large-ion lithophile elements (LILE) and high field strength elements (HFS), but higher abundances of first series transition metals (Fig. 4). The so-called ferromagnesian trace elements, Cr, Sc, V and Ni show moderately strong correlation with $\mathrm{Al}_{2} \mathrm{O}_{3}$. This may suggest that these ferromagnesian elements are chiefly controlled by the clay mineral chlorite.

The abundance of $\mathrm{Cr}$ and $\mathrm{Ni}$ in siliciclastic sediments are considered as a useful indicator in provenance studies. Average $\mathrm{Cr}$ and $\mathrm{Ni}$ abundances and $\mathrm{Cr} / \mathrm{Ni}$ ratios of average phyllites of the Birimian metasediments are 104.6 p.p.m., 68.8 p.p.m. and 1.52 respectively (Table 1), and for early Proterozoic upper crust are 59 p.p.m., 31 p.p.m and 1.90 [6]. According to Wrafter and Graham [18] a low concentration of $\mathrm{Cr}$ indicates a felsic provenance, and Bock et al. [19] have indicated that Ferromagnesian elements (eg., $\mathrm{Fe}, \mathrm{Cr}, \mathrm{Ni}$ ) are enriched in mafic and ultramafic igneous rocks and elevated abundances of these elements in the sediments and sedimentary rocks may indicate the addition of components derived from mafic lithologies. Elevated $\mathrm{Cr}$ and $\mathrm{Ni}$ abundances with low $\mathrm{Cr} / \mathrm{Ni}$ (between 1.3 and 1.5) were further suggested to be indicative of ultramafic rocks in source area of shales by Garver et al. [20]. The $\mathrm{Cr}$, Ni and $\mathrm{Cr} / \mathrm{Ni}$ data above suggest therefore a mafic source for the Birimian Phyllites.

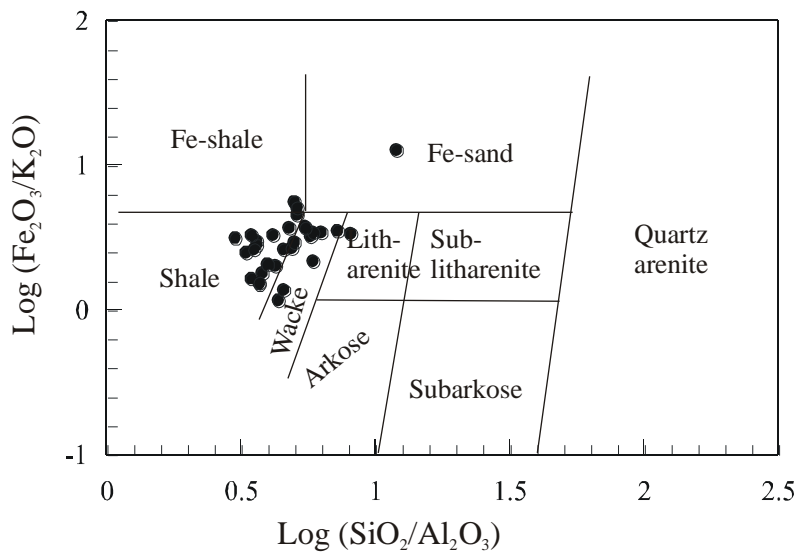

Fig. 3: The geochemical classification of the Birrimian phyllites (after [16]).

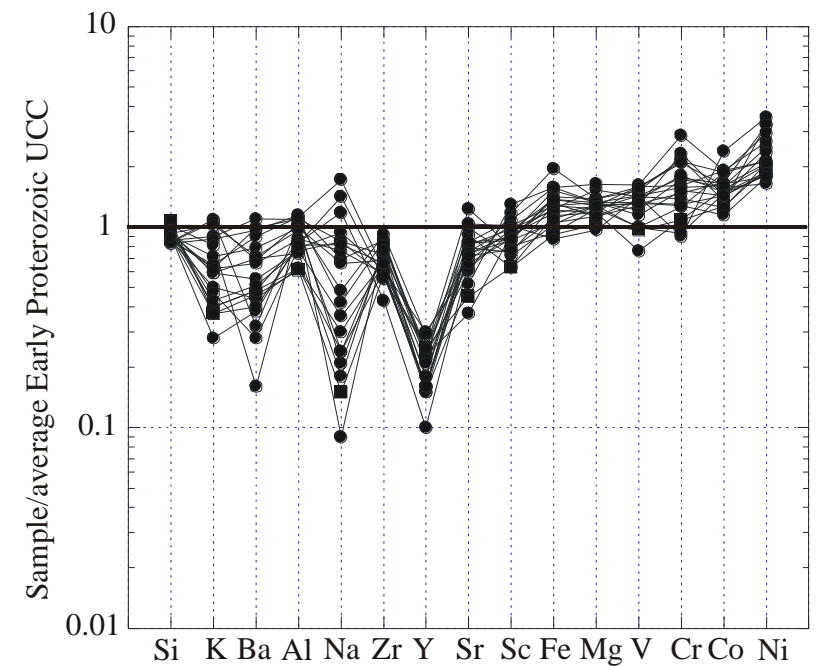

Fig. 4: Upper crust-normalized patterns for phyllite samples from the Birimian Supergroup of Ghana 


\begin{tabular}{|c|c|c|c|c|c|c|c|c|c|c|c|c|c|c|c|c|c|c|c|c|c|c|c|c|c|}
\hline & $10 / 6$ & $10 / 8$ & $18 / 08$ & $38 / 1$ & $38 / 3$ & $38 / 17$ & $38 / 19$ & $55 / 4$ & $55 / 8$ & $55 / 13$ & $55 / 14$ & $55 / 15$ & $1 / 4$ & $1 / 14$ & $8 / 58$ & $8 / 6$ & $8 / 8$ & 7/9 & $7 / 11$ & $8 / 1$ & 7/1 & $1 / 3$ & $1 / 7$ & $7 / 2$ & EPUC \\
\hline \multicolumn{26}{|c|}{ In wt. \% } \\
\hline $\mathrm{SiO}_{2}$ & 57.3 & 55.3 & 7.3 & 7.1 & 61.0 & 58.3 & 71.7 & 62.6 & & & & 62.4 & 62.9 & 57.1 & 61.6 & 62.9 & 64.6 & 54.8 & & & 57.1 & 62.9 & 60 & 65.4 & 66.9 \\
\hline $\mathrm{TiO}_{2}$ & & 0.2 & 0.2 & 0.1 & 0.2 & 0.3 & 0.3 & 0.2 & 0.1 & 0.1 & 0.3 & 0.2 & 0.1 & 0.1 & 0.1 & & & 0.3 & 0.2 & 0.1 & 0.4 & 0.3 & 0.1 & 0.1 & 0.6 \\
\hline $\mathrm{Al}_{2} \mathrm{O}_{3}$ & 16.2 & 17.1 & 15.2 & 15.2 & 14.8 & 16.4 & 9.1 & 11.0 & 9.2 & 3.8 & 15.5 & 14.5 & 11.3 & 16.7 & 13.0 & 12.5 & 11.3 & 18.6 & 16.7 & 15.5 & 16.5 & 12.7 & 12.9 & 12.1 & 14.9 \\
\hline $\mathrm{Fe}_{2} \mathrm{O}_{3}$ & 8.7 & 7.0 & 6.8 & 6.3 & 4.7 & 5.7 & 4.1 & 4.2 & 4.6 & 7.8 & 5.2 & 3.9 & 6.1 & 7.0 & 5.4 & 5.9 & 4.9 & 7.0 & 6.7 & 5.9 & 6.6 & 5.9 & 7.0 & 6.7 & 4.5 \\
\hline $\mathrm{MnO}$ & 0.06 & 0.10 & 0.06 & 0.20 & 0.30 & 0.10 & 0.20 & 0.30 & 0.20 & 0.30 & 0.20 & 0.10 & 0.08 & 0.05 & 0.09 & 0.07 & 0.09 & 0.09 & 0.02 & 0.06 & 0.07 & 0.09 & 0.10 & 0.09 & \\
\hline $\mathrm{MgO}$ & 2.7 & 2.6 & 2.6 & 2.7 & 2.2 & 2. & 2.0 & 2.4 & 2.5 & 6.4 & 2 & 1.9 & 2.6 & 3.2 & 2.3 & 2.2 & 2.5 & 3.0 & 1.4 & 2.3 & 2.5 & 2.1 & 2.3 & 2.3 & 1.95 \\
\hline $\mathrm{CaO}$ & 0 & 3.4 & 0.6 & 5.6 & 2.4 & & 1.8 & 4.3 & 4.8 & 14.0 & & 2.2 & 3.9 & 0.4 & 3.1 & & 2.3 & 0.9 & 1.5 & 2.0 & 1.9 & 2.3 & 2.9 & .6 & 3.2 \\
\hline $\mathrm{Na}_{2} \mathrm{O}$ & 1 & 2.3 & 0.3 & 0.7 & 2.2 & 2.8 & 0.5 & 0.6 & 1.0 & 0.3 & 1 & 0.8 & 1.2 & 5.7 & 2.5 & 9 & 2.8 & 5.2 & 0.9 & 3 & 2.1 & 2.1 & 2.0 & 1.4 & 3.3 \\
\hline $\mathrm{K}_{2} \mathrm{O}$ & 2 & 2.8 & 2.6 & 3.5 & 2.3 & 2.0 & 1.2 & 1.9 & 1.3 & 0.6 & 3.4 & 3.3 & 1.9 & 2.1 & 2.0 & 1.3 & 1.4 & 2.2 & 4.0 & 2.8 & 2.5 & 2.0 & 1.9 & 1.8 & 3.2 \\
\hline LOI & 8.7 & 9.3 & 6.0 & 8.0 & 9.6 & 9 & 7.2 & 12.1 & 10.6 & 23.4 & 13.0 & 8.9 & 10.8 & 8.5 & 9.0 & 7.0 & 8.1 & 9.4 & 12.1 & 8.7 & 9.2 & 8.5 & 10.2 & 9.2 & \\
\hline $\begin{array}{l}\text { Sum } \\
\text { In ppm }\end{array}$ & 99.0 & 100.1 & 101.7 & 99.4 & 99.7 & & 98.1 & 99.6 & 99.7 & 101.1 & 99.2 & 98.2 & 100.9 & 100.9 & 99.1 & 97.3 & 98.1 & 101.5 & 100.7 & 99.8 & 98.9 & 98.9 & 99.4 & 100.7 & \\
\hline $\mathrm{Ba}$ & 772 & 677 & 15 & 227 & 555 & 690 & 324 & 488 & 338 & 135 & $4 / 7$ & 494 & 387 & 628 & 461 & 336 & 357 & 536 & 114 & 665 & 665 & 665 & 261 & 632 & 700 \\
\hline $\mathrm{Sr}$ & 168 & 236 & 03 & 206 & 232 & & 25 & 343 & 27 & 768 & 06 & 291 & 191 & 145 & 226 & 185 & 201 & 185 & 217 & 30 & 371 & 78 & 204 & 175 & 280 \\
\hline $\mathrm{Sc}$ & 16.9 & 15.7 & 13.3 & 12.5 & 12.5 & 14.7 & 9.10 & 11.6 & 10.4 & 11.9 & 13.3 & 14.7 & 14.0 & 18.7 & 14.2 & 12.6 & 11.1 & 19.0 & 16.8 & 18.7 & 17.4 & 15.6 & 12.4 & 14.3 & 14.5 \\
\hline V & 129 & 116 & 98.8 & 123 & 111 & 117 & 78.5 & 81.3 & 80.1 & 63.5 & 106 & 115 & 108 & 131 & 127 & 104 & 107 & 203 & 455 & 141 & 138 & 107 & 83.4 & 80.3 & 81 \\
\hline $\mathrm{Cr}$ & 95.1 & 104 & 02 & 130 & 107 & 92.7 & 63.9 & 74.2 & 54.6 & 38.4 & 86.8 & 82 & 76 & 168 & 124 & 137 & 75.7 & 169 & 208 & 44 & 120 & 44.0 & 70.3 & 0.1 & 59 \\
\hline Co & 28.7 & 24.8 & 23.6 & 20.3 & 22.4 & 24 & 19 & 28.2 & 22.2 & 18.3 & 25 & 18.7 & 21.6 & 28.6 & 24 & 21.6 & 17.3 & 39.3 & 39.3 & 26.3 & 34.4 & 21.6 & 23.9 & 22.6 & 15 \\
\hline $\mathrm{Ni}$ & 65.9 & 55.3 & 51.3 & 101 & 58.5 & 77.2 & 60.4 & 66.1 & 56.1 & 52.7 & 100 & 64.5 & 57.1 & 83.1 & 65.1 & 57.7 & 55.1 & 108 & 199 & 63.4 & 52.9 & 22.8 & 48.1 & 29.4 & 31 \\
\hline Y & 7.30 & 7.30 & 7.30 & 4.70 & 5.80 & 8.00 & 8.10 & 8.10 & 5.80 & 9.30 & 9.30 & 7.00 & 6.66 & 4.90 & 5.00 & 3.30 & 5.00 & 6.74 & 9.00 & 3.30 & 6.70 & 5.01 & 5.00 & 5.00 & 32.00 \\
\hline $\mathrm{Zr}$ & 155 & 155 & 147 & 139 & 123 & 131 & 105 & 148 & 118 & 25.8 & 165 & 139 & 120 & 110 & 105 & 77.3 & 103 & 164 & 160 & 83.8 & 138 & 129 & 124 & 138 & 180 \\
\hline $\mathrm{Yb}$ & 1.29 & 1.28 & 1.29 & 1.20 & 1.20 & 1.20 & 1.20 & 1.50 & 2.10 & 2.40 & 2.40 & 2.40 & 1.74 & 1.72 & 1.73 & 1.73 & 1.74 & 2.30 & 2.30 & 1.72 & 1.74 & 1.74 & 1.73 & 3.48 & 2.32 \\
\hline & & & & 1.7 & 60.7 & & & 73.2 & & & & & 65.6 & & 67.0 & & & & & & 63.4 & & & 64.9 & 51.2 \\
\hline PIA & 77.8 & 65.3 & 92.6 & 83.5 & 63.4 & 68.5 & 82.8 & 81.8 & 70.6 & 76.0 & 69.0 & 80.7 & 70.5 & 59.0 & 71.9 & 79.7 & 76.3 & 61.6 & 80.6 & 62.9 & 66.8 & 60.6 & 62.6 & 68.8 & 51.5 \\
\hline ICV & 1.0 & 1.1 & 0.9 & 1.2 & 0.9 & 0.9 & 1.1 & 1.2 & 1.6 & 7.7 & 0.9 & 0.8 & 1.4 & 1.1 & 1.2 & 1.2 & 1.2 & 1.0 & 0.9 & 1.0 & 1.0 & 1.2 & 1.3 & 1.1 & \\
\hline
\end{tabular}

$\mathrm{CIA}$, Chemical Index of Alteration; PIA, Plagioclase Index of Alteration; ICV, Index of Compositional Variability

\subsection{Paleoweathering conditions and metasomatism}

The Chemical Index of Alteration (CIA) is widely used to quantify the degree of source-area weathering and to constrain the paleoweathering conditions of ancient shales [21, 22, 23]. This index, defined as Nesbitt and Young [21]: $\mathrm{CIA}=\left[\mathrm{Al}_{2} \mathrm{O}_{3} /\left(\mathrm{Al}_{2} \mathrm{O}_{3}+\mathrm{CaO}^{*}+\mathrm{Na}_{2} \mathrm{O}+\mathrm{K}_{2} \mathrm{O}\right)\right] \times 100$ (in molar proportions), where $\mathrm{CaO} *$ represents the $\mathrm{CaO}$ content in the silicate fraction, measures the degree of feldspar alteration to aluminous clay minerals. Values of about 50 indicate fresh bedrock (no chemical weathering), and values close to 100 indicate complete conversion of feldspars to clay minerals (intense chemical weathering; [22,23]). CIA values for the analyzed phyllites are variable and typically range from 57.6 to 80.1 (average 66.7).

Paleoweathering conditions as well as post-depositional $\mathrm{K}$ metasomatism can be visualized in an $\mathrm{Al}_{2} \mathrm{O}_{3}-\mathrm{CaO}+\mathrm{Na}_{2} \mathrm{O}-$ $\mathrm{K}_{2} \mathrm{O}(\mathrm{A}-\mathrm{CN}-\mathrm{K})$ diagram (Fig. 5). From this diagram, trends resulting from the chemical weathering of crystalline bedrock are roughly parallel to the $\mathrm{A}-\mathrm{CN}$ boundary; however, K-metasomatism may result in significant departure from the predicted weathering trend [24]. The analyzed Birimian phyllites, plotted in A-CN-K diagram (Fig. 5), define a linear array that is distinctly different from the expected weathering trend. A straight line through the data intersects the feldspar join at a point indicating the fresh composition of potential bedrock; in this case the bedrock source is dominantly basaltic in composition. The weathering trend as depicted in the A-CN-K diagram (Fig. 5) indicate that the analysed phyllites have undergone post-depositional K metasomatism (due possibly to K-metasomatism of kaolinite to illite). This observation is consistent with earlier provenance studies on the Birimian metasediments [12,10]. From Fig. 5 it is possible to calculate the pre-K metasomatism CIA following the method of Fedo et al. [22]. The calculated pre-K metasomatism CIA values for the analyzed samples range from 55 to 85 (Fig. 5) suggesting low to moderately high degree of source area weathering. 


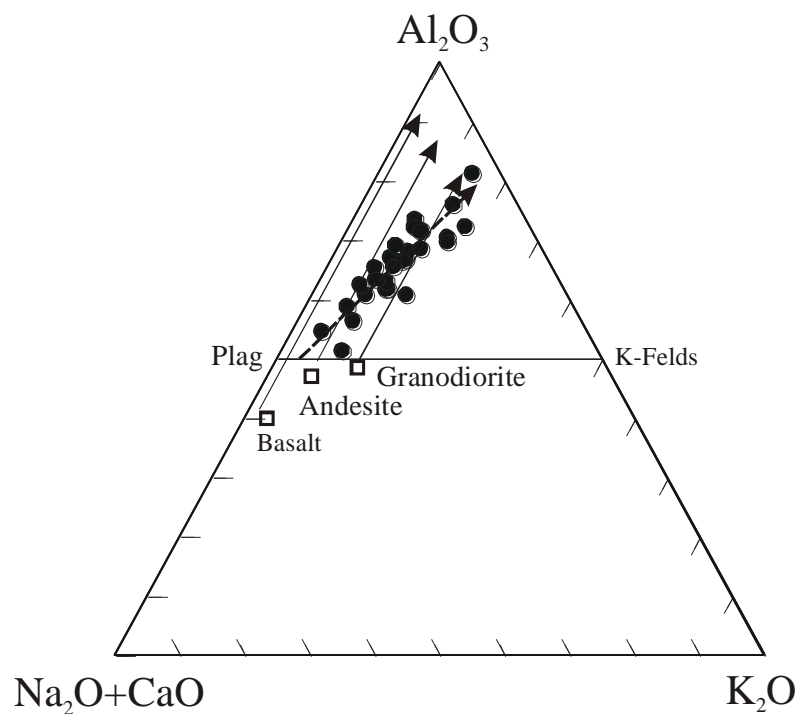

Fig. 5: ACNK diagram for the Birimian phyllites from the Birimian Supergroup of Ghana(after [22]).

\section{Provenance}

The geochemical signatures of clastic sediments have been used to find out the provenance characteristics $[4,25,26$, 27].

Based on geochemical data the Birimian phyllites presented here may be compared with clastic rocks from different tectonic setting in Australia and New Zealand [28]. On the binary relation of $\mathrm{SiO}_{2}$ versus $\mathrm{K}_{2} \mathrm{O} / \mathrm{Na}_{2} \mathrm{O}$, the Birimian phyllites dominantly plot in the active continental margin and with some straddling around the passive margin setting (Fig. 6) probably due to K-metasomatism effect in the area (Fig. 5). Therefore, the major element characteristics of the phyllites suggest an active continental margin setting.

The major element data/analysis above indicates illites predominance in the clays. However, the $\mathrm{Al}_{2} \mathrm{O}_{3}$ and $\mathrm{K}_{2} \mathrm{O}$ averages are relatively poor which does not suggest a granitic source or recycled mud but rather a possible source from mafic/volcanic material.

The Birimian phyllites have shown enrichment in $\mathrm{Cr}$ and $\mathrm{Ni}$ but with low $\mathrm{Cr} / \mathrm{Ni}$ ratio which is suggestive also of a mafic/ultramafic source material as elaborated above. The CIA values point to this possible mafic source material as composed predominantly of a basaltic parent material.

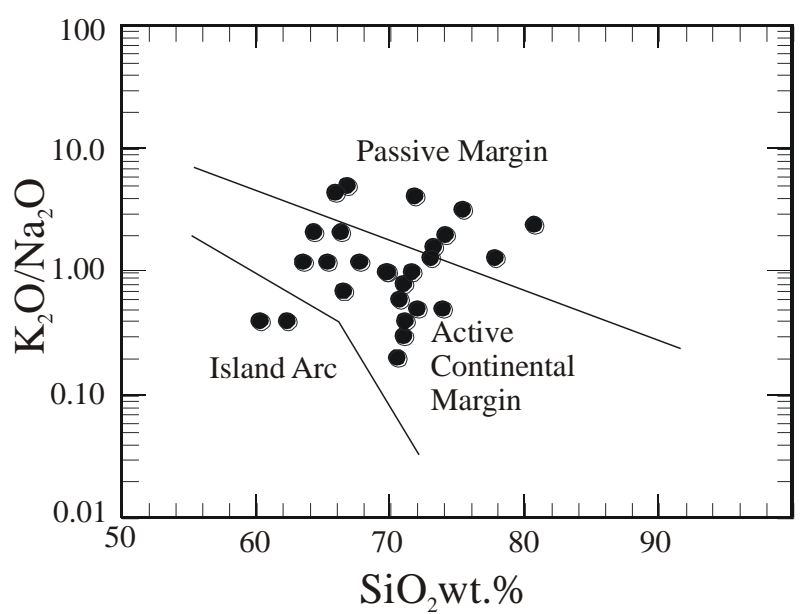

Fig. 6: Tectonic discrimination diagram for the Birimian Phyllites of Ghana (after [28]) 


\section{Conclusion}

The Proterozoic phyllites of the Birimian Supergroup generally indicate a single geochemical group by their major- and trace-element abundances. Their low to moderately high CIA values suggest that these rocks experienced a relatively weak to moderately high chemical weathering from a basaltic source rock. The transition metal geochemistry as well as $\mathrm{SiO}_{2}-\mathrm{K}_{2} \mathrm{O} / \mathrm{Na}_{2} \mathrm{O}$ binary plot also support that these phyllites originated from a mafic igneous source and were deposited in an active continental margin setting.

\section{Acknowledgement}

We acknowledge D. Zachman at the Geochemical Laboratory of the Technical University at Braunschweig, Germany for the geochemical analysis of the samples and the Deutscher Akademischer Austauschdienst ( DAAD) for the financial assistance.

\section{References}

[1] Batia, M.R., Crook, K.A.W., "Trace element characteristics of graywackes and tectonic setting discrimination of sedimentary basins", Contributions to Mineralogy and Petrology, Vol. 92, (1986), pp. 181-193.

[2] McLennan, S. M., Hemming, S. R., Taylor, S.R., et al., Early Proterozoic crustal evolution: geochemical and Nd-Pb isotopic evidence from metasedimentary rocks, southwestern North America. Geochimica et Cosmochimica Acta. Vol. 59, (1995), pp. 1153-1177.

[3] Asiedu, D. K., Hegner, E., Rocholl, A., "Provenance of Late Ordovician to Early Cretaceous sedimentary rocks from southern Ghana, as inferred from Nd isotopes and trace elements", Journal of. African. Earth Science, Vol. 41, (2005), pp. 316-328.

[4] Taylor, S.R., McLennan, S.M., "The continental crust: its composition and evolution". Blackwell Scientific Publications, Oxford, UK, 1985, pp. 312 .

[5] Condie, K.C., "Plate Tectonics and Crustal Evolution”, Butter-worth-Heinemann, Oxford, 1997, pp. 282.

[6] Condie, K.C., "Chemical composition and evolution of the upper continental crust: contrasting results from surface samples and shales", Chemical Geology, Vol 104, (1993), pp. 1-37.

[7] Boher, M., Abouchami, W., Michard, A., et al., "Crustal growth in West Africa at 2.1 Ga”, Journal of Geophysical Research, Vol. 95, (1992), pp. 345-369.

[8] Taylor, P.N., Moorbath, S., Luebe, A., et al., "Early Proterozoic crustal evolution in the Birimian of Ghana: constraints from geochronology and isotope geochemistry", Precambrian Research, Vol. 56, (1992), pp. 97-111.

[9] Asiedu, D.K., Dampare, S., Asamoah-Sakyi, P., et al., "Geochemistry of Paleoproterozoic metasedimentary rocks from the Birim diamondiferous field, southern Ghana: Implications for provenance and crustal evolution at the Archean-Proterozoic boundary", Geochemical Journal, Japan, Vol. 38, (2004), 215-228.

[10] Asiedu, D.K., Kutu, J.M., Manu, J., et al., "Geochemistry and provenance of metagreywackes from the Konongo area, Southwestern Ghana", African Journal of Science Techology,Vol. 10, No.1, (2009), 37-44.

[11] Karikari, F., Ferrière1, L., Koeberl, C., et al., "Petrography, geochemistry, and alteration of country rocks from the Bosumtwi impact structure, Ghana", Meteoritic and Planetary Science Vol. 42, (2007), pp. 513-540.

[12] Roddaz, M., Debat, P., Nikiéma, S., "Geochemistry of Upper Birimian sediments (major and trace elements and Nd-Sr isotopes) and implications for weathering and tectonic setting of the Late Paleoproterozoic crust", Precambrian Research, Vol. 159, (2007), pp. 197211.

[13] Sylvester, P.J., Attoh, K., "Lithostratigraphy composition of 2.1 Ga greenstone belts of the West African Craton and their bearing on crustal evolution and the Archaean-proterozoic boundary", Journal of Geology, Vol. 100, (1992), pp. 377-393.

[14] Abouchami, W., Boher, M., Michard, A., et al., "A major 2.1 Ga old event of mafic magmatism in West Africa: An early stage of crustal accretion”, Journal of Geophysical Research, Vol. 95, (1990), pp. 17605-17629.

[15] Ntiamoah-Agyakwa, Y., "Relationship between gold and manganese mineralizations in the Birimian of Ghana, West Africa", Geological Magazine, Vol. 116, No. 5, (1979), pp. 345-352.

[16] Herron, M. M., "Geochemical classification of terrigenous sands and shales from core or log data", Journal of Sedimentary Petrology, Vol. 58, No. 5, (1988), pp. 820-829.

[17] Cox, R., Lowe, D., Cullers, R.L., "The influence of sediment recycling and basement composition on evolution of mudrock chemistry in the southwestern United States", Geochimica et Cosmochimica Acta, 59, (1995), pp. 2919-2940.

[18] Wrafter, J.P., Graham, J.R., "Ophiolitic detritus in the Ordovician sediments of South Mayo Ireland", Journal Geological Society of London, Vol. 146, (1989), pp. 213-215.

[19] Bock, B., McLennan, S.M., Hanson, G.N., "Geochemistry and provenance of the Middle Ordovician Austin Glen Member (Normanskill Formation) and the Taconian Orogeny in New England", Sedimentology, Vol. 45, (1998), pp. 635-655.

[20] Garver, J.I., Royce, P.R., Smick, T.A., "Chromium and Nickel in shale of Taconic foreland: a case study for the provenance of fine-grained sediments with an ultramafic source", Journal of Sedimentary Research, Vol. 100, (1996), pp. 100-106.

[21] Nesbitt, H. W., Young, G.M., "Early Proterozoic climates and plate motions inferred from major element chemistry of lutites", Nature, Vol. 299, (1982), pp. 715-717.

[22] Fedo, C.M., Nesbitt, H.W., and Young, G.M., "Unravelling the effects of potassium metasomatism in sedimentary rocks and paleosoils, with implications for paleoweathering conditions and provenance", Geology, Vol. 23, (1995), pp. 921-924.

[23] Fedo, C.M., Eriksson, K., Krogstad, E.J., "Geochemistry of shale from the Archean ( 3.0 Ga) Buhwa Greenstone belt, Zimbabwe: Implications for provenance and source area weathering", Geochimica et Cosmochimica Acta, Vol. 60, No. 10, (1996), pp. 1751-1763.

[24] Fedo, C.M., Young, G.M., Nesbitt, H.W., "Paleoclimatic control on the composition of the Paleoproterozoic Serpent Formation, Huronian Supergroup, Canada: a greenhouse to icehouse transition”, Precambrian Research, Vol. 86, (1997), pp. 201-223. 
[25] Condie, K.C., Boryta, M.D., Liu, J., et al., "The origin of khondalites: geochemical evidence from the Archean to Early Proterozoic granulitic belt in the North China Craton", Precambrian Research, Vol. 59, No 3-4, (1992), pp. 207-223.

[26] Cullers, R.L., "The controls on the major and trace element evolution of shales, siltstones and sandstones of Ordovician to Tertiary age in the Wet Mountain region, Colorado, U.S.A", Chemical Geology, Vol. 123, No. 1-4, (1995), pp. 107-131

[27] Armstong-Altrin, J.S., Lee Y.I., Verma, S.P., et al., "Geochemistry of sandstones from the upper Miocene Kudankulam Formation, southern India: Implications for provenance, weathering, and tectonic setting”, Journal of Sedimentary Research, Vol. 72, No. 2, (2004), pp. $285-297$.

[28] Roser, B.P., Korsch, R.J., "Determination of tectonic setting of sandstone- mudstone suites using SiO2 content and K2O/Na2O ratio", Journal of Geology, Vol. 94, (1986), pp. 635-650.

[29] Milesi, J. P., Feybesse, J. L., Ledru, P., et al., “ Les mineralisations auriferes de l'Afrique de l'Ouest. Leur evolution lithostructurale au Proterozoique inferieur, Carte metallogenique a 1/2 000 000”, Chronique de la recherché miniere, France, Vol. 497, (1989), pp. 98 